\title{
Cardiovascular risk factors in young Mexican adults
}

\author{
Factores de riesgo cardiovascular en adultos jóvenes mexicanos \\ Marco A. Almazán-Ávila* \\ Faculty of Medicine of the Autonomous University of the State of Mexico, Toluca de Lerdo, State of Mexico, Mexico
}

\begin{abstract}
Background: Cardiovascular diseases (CVDs) are the main cause of morbidity and mortality in the adult population worldwide. Most studies on risk factors have focused on children and adults of mature age. Quite the opposite, there are few which specifically analyze young individuals. Objectives: The objectives of the study were to determine cardiovascular risk factors in young Mexican adults. Materials and methods: A cross-sectional, descriptive, and observational study was carried out on a healthy sample of 198 young Mexican university-level adults, aged from 18 to 25 years who, after completing a questionnaire, were evaluated on anthropometric and blood pressure parameters. A comparative analysis of the results was made according to sex and with findings from other studies. Results: In 46\% of the subjects, an atherogenic diet was identified (predominant among males). About $59.1 \%$ of the individuals were classified as sedentary (mostly women). About $91.4 \%$ of the sample had two or more associated antecedents of CVD (and other associated conditions) in their family background, the most frequent being diabetes mellitus (71.2\%), systemic hypertension (64.6\%), and overweight or obesity (56.6\%). In $25.8 \%$ of the individuals, overweight was observed (more frequent among women). In males, a higher proportion of alterations in blood pressure levels was described. Conclusions: The most frequently identified findings correspond to the group of modifiable minor risk factors, which could allow the development of preventive measures, inasmuch as these are subjects in which the modification of harmful behaviors and habits is achievable and timely.
\end{abstract}

Key words: Cardiovascular. Risk. Factors. Young. Mexican. Adults.

\section{Resumen}

Antecedentes: Las enfermedades cardiovasculares (ECV) son la principal causa de morbimortalidad en la población adulta a nivel mundial. La mayor parte de los estudios sobre factores de riesgo han focalizado su atención en niños y adultos de edad madura. Por el contrario, resultan escasos aquellos que analicen específicamente individuos jóvenes. Objetivo: Determinar los factores de riesgo cardiovascular en adultos jóvenes mexicanos. Material y métodos: Estudio observacional, descriptivo y transversal, realizado en una muestra sana de 198 adultos jóvenes mexicanos de nivel universitario de 18 a 25 años a quienes, tras completar un cuestionario, se les evaluaron parámetros antropométricos y de tensión arterial. Se hizo un análisis comparativo de los resultados de acuerdo con el sexo y con hallazgos de otros estudios. Resultados: En el $46 \%$ de los sujetos se identificó una dieta aterogénica (predominante entre varones). El $59.1 \%$ de los individuos se clasificaron como sedentarios (en su mayoría mujeres). El 91.4\% de la muestra cuenta con dos o más antecedentes heredofamiliares de ECV (y otras condiciones asociadas), siendo los más frecuentes la diabetes mellitus (71.2\%), la hipertensión arterial

Correspondence:

Marco A. Almazán-Ávila

E-mail: almazan.avila@gmail.com
Date of reception: 15-06-2019

Date of acceptance: 29-03-2020

DOI: 10.24875/ACME.M20000162
Available online: 02-09-2020

Arch Cardiol Mex. 2020;90(4):391-399 www.archivoscardiologia.com 2604-7063/@ 2020 Instituto Nacional de Cardiología Ignacio Chávez. Published by Permanyer. This is an open access article under the CC BY-NC-ND license (http://creativecommons.org/licenses/by-nc-nd/4.0/). 
sistémica (64.6\%) y el sobrepeso u obesidad (56.6\%). El 25.8\% de los individuos cursó con sobrepeso (más frecuente entre mujeres). En los varones se presentó una mayor proporción de alteraciones en los niveles de tensión arterial. Conclusiones: Los hallazgos identificados con mayor frecuencia corresponden al grupo de factores de riesgo menores modificables, lo cual podría permitir el desarrollo de medidas preventivas, al tratarse de sujetos en quienes es asequible la modificación de conductas y hábitos nocivos.

Palabras clave: Factores. Riesgo. Cardiovascular. Adultos. Jóvenes. Mexicanos.

\section{Introduction}

Cardiovascular diseases (CVDs) are the main cause of morbidity and mortality in the adult population, both in developed and developing countries ${ }^{1,2}$, since they represent about $30 \%$ of all deaths $3^{3,4}$ and about $50 \%$ of deaths associated with non-communicable diseases ${ }^{4}$. In addition, there are certain current trends that contribute to its increase, such as population growth or longer average life expectancy, and increased risk factors attributable to the characteristic lifestyles of industrialized cities 5,6 . Such is the case of Mexico, where a notable displacement of the population from rural to urban areas has occurred in the past decades, which, in turn, has led to changes in diet (promoting an atherogenic diet) and to sedentariness ${ }^{3,5}$.

CVDs integrate a group of conditions which find their origin in cardiac and blood vessel disorders and that entail a poor tissue blood supply due to a diseased vascular source. Among these, ischemic cardiomyopathy (IC) and cerebrovascular accidents (CVA) stand out, followed by systemic arterial hypertension (SAH) (also considered as an independent risk factor for other CVDs) and peripheral vascular disease (PVD) ${ }^{4,7}$. About $80 \%$ of the mortality associated with this group of non-communicable diseases is attributed to these entities ${ }^{4}$.

Regarding its etiology, it is considered multifactorial and complex, insomuch as factors inherent to the individual (e.g., physiological, biochemical, genetics, lifestyles and habits) and its environment (e.g., the urbanization and the community, in which its socioeconomic and cultural context develops) intervene synergistically in its genesis 8,9 . The underlying situation is atherosclerosis, which develops progressively over the years in a silent manner, so the onset of symptoms generally occurs at middle age, when the atherosclerotic process is already at an advanced stage ${ }^{10,11}$.

Nevertheless, evidence shows the appearance of early atherosclerotic detrimental changes ${ }^{11-13}$, as a result of the joint action of cardiovascular risk factors (CVRFs) which are present from early childhood, and therefore, there is a longer time of exposure to them (since the effects of unhealthy diets, sedentary lifestyle, childhood obesity, high blood pressure and elevated levels of LDL cholesterol on the arterial system are cumulative), which, in turn, leads to an increased risk of cardiovascular morbimortality in adult life $e^{11,14}$.

In addition, there is an association of individual and sociocultural aspects, such as exposure to tobacco smoke (passive smoking) and the tendency for CVRFs to continue until adulthood, inasmuch as some risk factors are determined by the behaviors or habits learned since childhood or adolescence ${ }^{15,16}$, while others are acquired during the initial years of adult life, as consequence of greater independence ${ }^{12,15,17}$.

CVRFs correspond to those biological signs, acquired habits and characteristics of the individual that are most frequently associated with the statistical risk to predispose the development of a CVD in the coming years ${ }^{18,19}$. CVDs are preventable if measures on these factors are taken, some of which are fortunately modifiable ${ }^{4,20}$; the World Health Organization (WHO) considers as CVRFs: systemic arterial hypertension, overweight, obesity, inadequate diet (atherogenic), dyslipidemia (hypercholesterolemia, hypertriglyceridemia, increased LDL cholesterol, and decreased HDL cholesterol), smoking, alcohol consumption, physical inactivity or sedentariness, male sex, age (men $>55$ years, women $>65$ years), family background and genetics, stress, diabetes mellitus, and the presence of another $C V D^{5,8,21}$.

Although each CVRF represents an independent impact on health, the association of two or more risk factors in an individual is not uncommon, especially now as sedentary lifestyles predominate over the population $^{22,23}$. The more risk factors are present in an individual, the likelihood of presenting CVD increas$\mathrm{es}^{12,24}$, insomuch as they act in a synergistic way in its physiopathology 20 .

The seventh report of the Joint National Committee for the prevention, detection, evaluation, and treatment of arterial hypertension (JNC 7), as well as other guidelines, refers to CVRFs as major or independent and minor; likewise, modifiable and non-modifiable factors are recognized ${ }^{25,26}$ (Table 1). 
Table 1. Major and minor risk factors for cardiovascular disease

\begin{tabular}{|c|c|}
\hline Major risk factors & Minor risk factors \\
\hline Modifiable & Modifiable \\
\hline $\begin{array}{l}\text { - Systemic arterial hypertension } \\
\text { - Smoking } \\
\text { - Dyslipidemia } \\
\text { - Diabetes mellitus or other CVD } \\
\text { - Microalbuminuria or GFR < } 60 \\
\text { mL/min }\end{array}$ & $\begin{array}{l}\text { - Overweight and obesity } \\
\text { - Sedentariness } \\
\text { - Atherogenic diet } \\
\text { - Alcohol consumption } \\
\text { - Stress }\end{array}$ \\
\hline Non-modifiable & Non-modifiable \\
\hline $\begin{array}{l}\text { - Age (men }>55 \text { years, women }> \\
65 \text { years) } \\
\text { - Male sex } \\
\text { - Premature CVD family } \\
\text { background (men }<55 \text { years, } \\
\text { women }<65 \text { years) }\end{array}$ & $\begin{array}{l}\text { - Late CVD family } \\
\text { background (men }>55 \\
\text { years, women }>65 \text { years) }\end{array}$ \\
\hline
\end{tabular}

CVD: cardiovascular disease; GFR: glomerular filtration rate ${ }^{26,27}$

Behavioral risk factors, such as smoking, unhealthy diets and physical inactivity, depict by themselves about $80 \%$ of the causes that lead to a cardiovascular complication, ${ }^{4,27}$ so that the efficiency in the prevention of CVDs depends on the adequate knowledge about CVRFs $^{5}$.

Most studies on CVRFs (as well as the strategies on prevention, detection, and treatment of CVDs) have focused their attention on children, adolescents, the elderly ${ }^{28}$ and mainly on adults of mature age (particularly those aged over 40 years) $)^{11,28}$; on the contrary, those which analyze specifically the individuals who are at the beginning of adulthood (18-25 years) are scarce so far ${ }^{15}$.

Some research carried out in different countries (Mexico, Argentina, Chile, Spain and Venezuela $)^{18}$, consistently reveals an increase in the incidence of CVRFs in young populations; these studies are striking since they argue that the cardiovascular risk profile in young people may be different to the one found in adults, as they might develop a CVD in the absence of classic CVRFs $^{5,9,18}$.

By demonstrating that CVDs can manifest from these ages, a field of research on CVRFs affecting these age groups is exposed, inasmuch as it is important to study the relationship between the pathogenesis of CVDs and the lifestyle of young adults (who are not exempt) ${ }^{2,18}$. Prospective studies have shown that the presence of abnormal blood pressure levels in young patients has a direct association with the development of CVD in future ${ }^{29}$.
When considering the results obtained from the National Health and Nutrition Survey conducted in Mexico in 2016 (Encuesta Nacional de Salud y Nutrición, ENSANUT 2016), it was observed that $5.4 \%$ of young adults aged from 20 to 29 years suffered from systemic arterial hypertension ${ }^{30}$. On the other hand, in the last census of the National Institute of Statistics and Geography (Instituto Nacional de Estadística y Geografía, INEGI), carried out in 2015 , it was reported that $16.6 \%$ of its Mexican inhabitants corresponded to the population aged between 20 and 29 years $^{31}$. Correlating this data with the results provided by ENSANUT 2016, it could be estimated that about 1.07 million young adults in Mexico suffered from systemic arterial hypertension and among these, only around $53.78 \%$ knew it ${ }^{31}$.

Thus, the identification of CVRFs within a population of young adults enables to determine their susceptibility and to route the development of preventive measures, as they are subjects in which the modification of harmful behaviors and habits is attainable, with the aim of promoting healthy lifestyles to reduce the risk (or to delay the development) of cardiovascular origin conditions $\mathbf{1}^{1,18,32}$.

\section{Materials and Methods}

A cross-sectional, descriptive and observational study was conducted in a population integrated by 1066 university students from the Faculty of Chemistry of the Autonomous University of the State of Mexico (Facultad de Química de la Universidad Autónoma del Estado de México, UAEM), within the range from 18 to 25 years old, during the period from October 2018 to June 2019, from which a representative, simple and random sample was selected, using the following formula for finite populations $n=\frac{N\left(Z_{a}^{2} p\right) q}{d^{2}(N-1)+\left(Z_{a}^{2} p q\right)}$. As a result, a sample of 283 university adults was integrated, to which an additional $10 \%$ was added, considering the possible losses, and a total of 311 apparently healthy participants (without the presence of pre-existing cardiovascular or metabolic disease) with Mexican nationality were obtained, all of whom granted their informed consent. A questionnaire structured in five sections evaluating: (1) characteristics of the diet, (2) characteristics of physical activity, (3) consumption of tobacco and alcohol, (4) level of stress, and (5) familiar background of CVDs, was applied to this sample.

This questionnaire was based on the validated instruments corresponding to ENSANUT 2016 from the Mexican National Institute of Public Health (Instituto 
Nacional de Salud Pública, INSP) ${ }^{33}$, the International Physical Activity Questionnaire "IPAQ"34, the Global Adult Tobacco Survey, ${ }^{35}$ and the Alcohol Use Disorders Identification Test ${ }^{36}$, both from the WHO, as well as the Work Stress Test of the Mexican Institute of Social Security (Instituto Mexicano del Seguro Social, IMSS) ${ }^{37}$. Subsequently, each of the participants was scheduled an individual appointment to determine their levels of blood pressure, weight, height, body mass index (BMI), abdominal and hip circumference, and waist-to-hip ratio (WHR).

The obtained results were collected in frequency tables for further statistical analysis, which, in turn, was represented as tables and bar graphs, showing the absolute and relative frequencies of each of the variables. For this purpose, the "Microsoft Office Excel Professional Plus 2016" and "Microsoft Office Power Point Professional Plus 2016" software were used.

\section{Results}

The questionnaire was applied to a sample of 311 young Mexican university-level adults, who were subsequently scheduled an individual appointment for the measurement of anthropometric and blood pressure values. To this appointment, only 198 university students attended $(67$ men $=33.8 \%$ and 131 women $=66.2 \%)$, due to the fact that some of them were either working on final projects or studying for exams and were not able to show up (even after one phone call reminder and granting a second opportunity to attend an open appointment), so the final sample was reduced to that number. The established age range was from 18 to 25 years old, with an average of 19.7 years.

In $46 \%$ of the subjects, an atherogenic diet was identified, being more predominant among males (49.2\%) than females $(44.3 \%)$. Although $47 \%$ of the sample consumes fruits from 5 to 7 days/week, $73.2 \%$ consume only one or two out of the five recommended servings per day. Regarding the consumption of fast food, $68.2 \%$ reported doing it from 1 to 2 days a week and $16.7 \%$ does so from 3 to 4 times a week. Meanwhile, $48.5 \%$ consume soda from 1 to 2 days/week and $13.6 \%$ up to 4 days/week.

As for the level of physical activity, $40.9 \%$ of the sample reported they carried out moderate or intense physical activity in the past 6 months, while $59.1 \%$ of the subjects would be classified as sedentary (Fig. 1), being higher the level of physical inactivity among women $(64.1 \%)$ than men (49.3\%). The main reasons why individuals affirmed not performing physical activity were the lack of time $(43.9 \%)$, lack of interest $(5.6 \%)$, in adequate urban spaces and insecurity $(4.5 \%)$, as well as

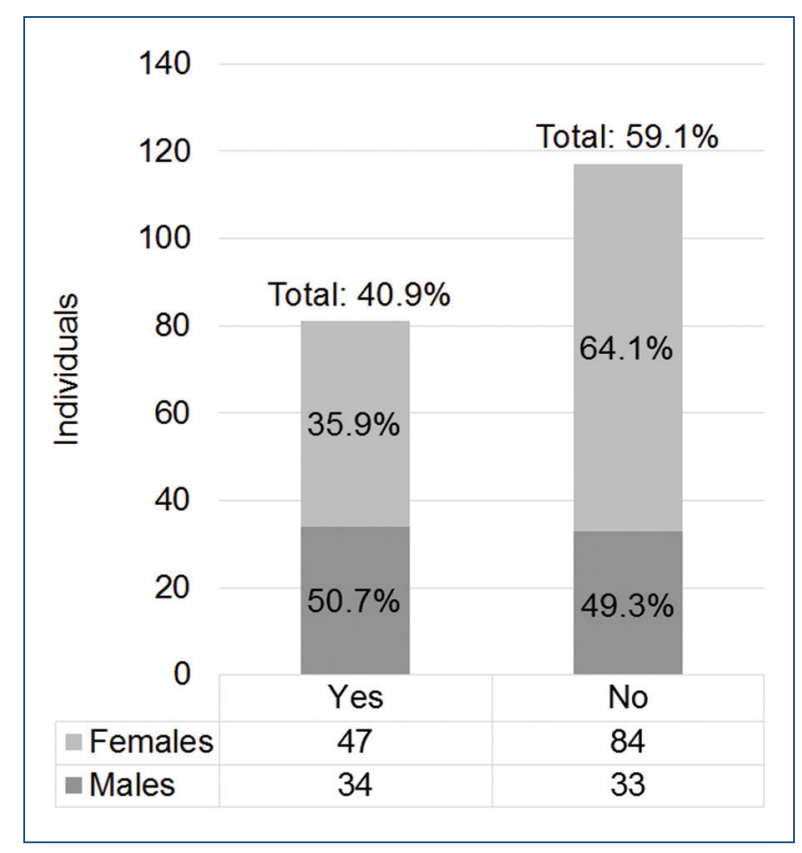

Figure 1. Individuals who have performed moderate or intense physical activity in the past 6 months.

the lack of knowledge about what activities they could perform (5.6\%). Concerning the time they usually spend in front of a screen (television, computer, videogames, cell phone, or electronic tablet), $41.9 \%$ allocate from 3 to 4 hrs a day.

On the subject of tobacco consumption, the results showed that $78.3 \%$ of individuals have never smoked, while $9 \%$ have quit smoking and $12.6 \%$ are currently smokers, who mostly consume about one or two cigarettes with a frequency of 1 or 2 times/week, with tobacco consumption being a little higher among women (13\%) compared to men (11.9\%). The age at which a greater frequency was observed about the beginning of tobacco consumption was at 17 years old.

With regard to alcohol consumption, $64.1 \%$ asserted that they usually consume alcoholic beverages, with higher consumption among men (76.2\%) than between women (58\%); however, most of them refer doing it only 1 or 2 times/month, consuming from 1 up to 4 drinks per occasion (Table 2).

Regarding the stress level, it was found that in $32.8 \%$ of individuals, it can be classified as medium, highlighting that frequently (or relatively frequently) they manifest inability or difficulty to get to sleep, headaches, indigestion and gastrointestinal discomfort, increased tendency to eat, drink or smoke more than usual, muscle tremors or nervous tics, as well as a constant sensation of fatigue or exhaustion. 
Table 2. Tobacco and alcohol consumption according to sex

\begin{tabular}{|c|c|c|c|c|c|c|}
\hline \multirow[t]{3}{*}{ Variables } & \multicolumn{2}{|c|}{ Males } & \multicolumn{2}{|c|}{ Females } & \multicolumn{2}{|c|}{ Total } \\
\hline & $\mathbf{n}$ & $\%$ & $\mathbf{n}$ & $\%$ & n & $\%$ \\
\hline & 67 & 33.8 & 131 & 66.2 & 198 & 100 \\
\hline $\begin{array}{l}\text { Tobacco consumption } \\
\text { Smoker } \\
\text { Non-smoker } \\
\text { Ex-smoker }\end{array}$ & $\begin{array}{c}8 \\
51 \\
8\end{array}$ & $\begin{array}{l}11.9 \\
76.2 \\
11.9\end{array}$ & $\begin{array}{c}17 \\
104 \\
10\end{array}$ & $\begin{array}{c}13 \\
79.4 \\
7.7\end{array}$ & $\begin{array}{c}25 \\
155 \\
18\end{array}$ & $\begin{array}{c}12.6 \\
78.3 \\
9\end{array}$ \\
\hline $\begin{array}{l}\text { Alcohol consumption } \\
\text { Yes } \\
\text { No }\end{array}$ & $\begin{array}{l}51 \\
16\end{array}$ & $\begin{array}{l}76.2 \\
23.8\end{array}$ & $\begin{array}{l}76 \\
55\end{array}$ & $\begin{array}{l}58 \\
42\end{array}$ & $\begin{array}{c}127 \\
71\end{array}$ & $\begin{array}{l}64.1 \\
35.9\end{array}$ \\
\hline
\end{tabular}

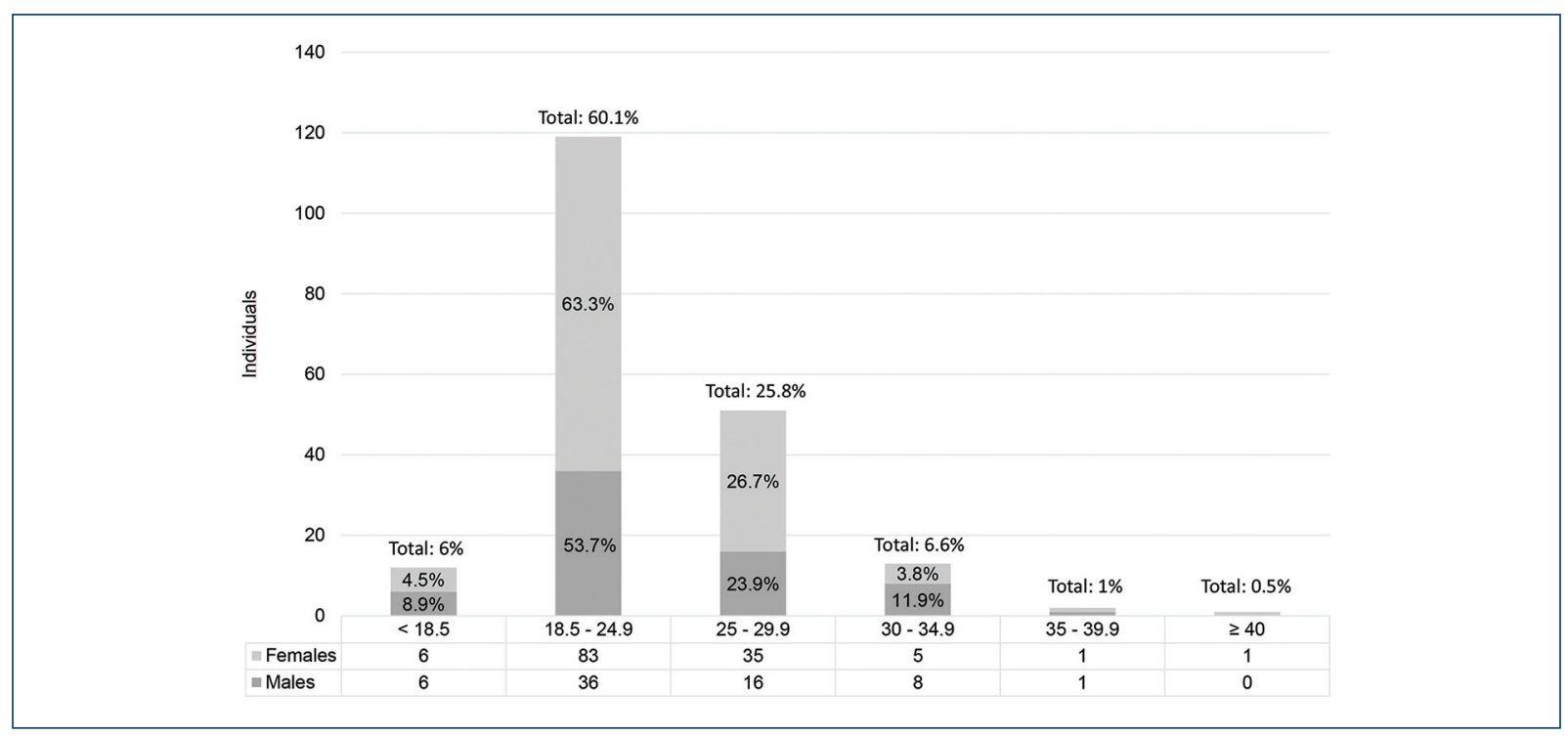

Figure 2. Body mass index according to sex.

With regard to genetic factors and family history, $91.4 \%$ of the subjects have a family background of CVD (and other associated conditions), the most frequent being diabetes mellitus (71.2\%), systemic arterial hypertension (64.6\%), and overweight or obesity (56.6\%). In turn, $44.4 \%$ of the individuals reported having from 3 to 4 antecedents of CVD in their family history, $36.4 \%$ referred from 1 to 2 , and $11.1 \%$ mentioned more than 5 . Moreover, $5.5 \%$ and $1.6 \%$ of the sample had a premature and late family history of acute myocardial infarction, respectively.

After obtaining the BMl of each of the participants, it was determined that $60.1 \%$ of them presented normal weight, $25.8 \%$ suffered from overweight (slightly more frequent among women than among men), and $8 \%$ from obesity (mostly observed in males) (Fig. 2). Besides, high values of abdominal circumference were found in $57.6 \%$ of the individuals, being higher among women (65.6\%) than among men (47.8\%). As for WHR, high values were recorded in $49 \%$ of young adults, with a clear predominance among women (64.1\%) over men (19.4\%).

The systolic blood pressure levels were normal ( $\leq 120 \mathrm{mmHg}$ ) in $71.2 \%$ of the individuals, while $15.2 \%$ presented high values $(121-129 \mathrm{mmHg})$ and $13.6 \%$ reflected a number above $130 \mathrm{mmHg}$. As for the diastolic blood pressure, $81.8 \%$ of the subjects had levels $\leq 80 \mathrm{mmHg}, 10.1 \%$ had levels between 80 to $89 \mathrm{mmHg}$, and only levels $>90 \mathrm{mmHg}$ were observed in $3 \%$. The mean arterial blood pressure was normal $(\leq 93 \mathrm{mmHg})$ in $82.3 \%$ of the subjects, whereas in $17.7 \%$, it was found to be high (> $93 \mathrm{mmHg}$ ). It is worth mentioning that it was men in whom a greater proportion of alterations in blood pressure levels was noticed. 
Table 3. Main cardiovascular risk factors findings according to sex

\begin{tabular}{|c|c|c|c|c|c|c|c|}
\hline \multicolumn{2}{|c|}{ Cardiovascular risk factors } & \multicolumn{2}{|c|}{ Males } & \multicolumn{2}{|c|}{ Females } & \multicolumn{2}{|c|}{ Total } \\
\hline & & n & $\%$ & n & $\%$ & n & $\%$ \\
\hline & & 67 & 33.8 & 131 & 66.2 & 198 & 100 \\
\hline \multirow[t]{2}{*}{ Major } & $\begin{array}{l}\text { Modifiable } \\
\text { Systemic arterial hypertension } \\
\text { Smoking }\end{array}$ & $\begin{array}{c}11 \\
8\end{array}$ & $\begin{array}{l}16.4 \\
11.9\end{array}$ & $\begin{array}{c}6 \\
17\end{array}$ & $\begin{array}{l}4.6 \\
13\end{array}$ & $\begin{array}{l}17 \\
25\end{array}$ & $\begin{array}{c}8.6 \\
12.6\end{array}$ \\
\hline & $\begin{array}{l}\text { Non-modifiable } \\
\text { Premature CVD family background* }\end{array}$ & 6 & 8.9 & 5 & 3.8 & 11 & 5.5 \\
\hline \multirow[t]{2}{*}{ Minor } & $\begin{array}{l}\text { Modifiable } \\
\text { Overweight } \\
\text { Obesity } \\
\text { Sedentariness } \\
\text { Atherogenic diet } \\
\text { Alcohol consumption } \\
\text { Stress }\end{array}$ & $\begin{array}{c}16 \\
9 \\
33 \\
33 \\
51 \\
22\end{array}$ & $\begin{array}{l}23.9 \\
13.4 \\
49.2 \\
49.2 \\
76.1 \\
32.8\end{array}$ & $\begin{array}{c}35 \\
7 \\
84 \\
58 \\
76 \\
43\end{array}$ & $\begin{array}{c}26.7 \\
5.3 \\
64.1 \\
44.3 \\
58 \\
32.8\end{array}$ & $\begin{array}{c}51 \\
16 \\
117 \\
91 \\
127 \\
65\end{array}$ & $\begin{array}{c}25.8 \\
8 \\
59.1 \\
46 \\
64.14 \\
32.8\end{array}$ \\
\hline & $\begin{array}{l}\text { Non-modifiable } \\
\text { Late CVD family background** }\end{array}$ & 17 & 25.4 & 14 & 10.7 & 31 & 1.6 \\
\hline \multicolumn{2}{|c|}{ Genetic factors and other family background of CVD*** } & 59 & 88 & 122 & 93.1 & 181 & 91.4 \\
\hline
\end{tabular}

CVD: cardiovascular disease

* Premature CVD family background: male relatives $<55$ years and female relatives $<65$ years.

** Late CVD family background: male relatives $>55$ years and female relatives $>65$ years.

***Systemic arterial hypertension, cerebrovascular accident, diabetes mellitus, overweight or obesity, atherosclerosis, peripheral vascular disease, familial hypercholesterolemia.

Hence, the main CVRFs found correspond to family history of CVD, sedentariness, atherogenic diet, stress, and overweight. On the other hand, the risk factors which presented a lower rate were alcohol consumption, smoking, high blood pressure and obesity (Table 3).

\section{Discussion}

Among the main findings of this study on CVRFs, carried out in a population of young Mexican university-level adults, a high family background burden was found, reinforced in turn by an insufficient physical activity, an atherogenic diet, a high level of stress, and a significant frequency of overweight. Even though some differences were perceived (both subtle and notable) in the incidence of certain factors between both sexes, the general risk outlook between women and men was similar.

Genetic factors and family background stood out since they were present in $91.4 \%$ of individuals, in whom diabetes mellitus, systemic arterial hypertension, and overweight or obesity emerged as the most frequent antecedents for CVD. Likewise, it was observed that most of the subjects presented from 2 up to more than 5 associated antecedents, which could mean an increase in the risk of suffering these or other CVD, inasmuch as there was also a strong relationship between the number of antecedents presented by each individual, with the alteration of their anthropometric parameters and blood pressure levels. This suggests a strong family correlation, either due to the implication of intrinsic genetic factors, or to the instructed customs and reinforced habits in the household, or a confluence of both situations.

Regarding the level of physical activity, more than half of the sample (59.1\%) was classified as sedentary, because the amount of physical activity they perform is insufficient to maintain an optimal energy balance, indicating as the main reason the lack of time (43.9\%), which could be attributed to the intense workload university students must meet. However, one factor that should be considered would be the amount of hours they spent in front of a screen (television, computer, videogames, cell phone, or electronic tablet) since at least $41.9 \%$ allocates from 3 to 4 hrs daily. When taking sex into account, it was women (64.1\%) in whom a higher level of physical inactivity was observed, which is a common finding with other studies conducted in Chile ${ }^{16,32}$ and in Spain ${ }^{1,17}$.

This situation is aggravated when considering that $46 \%$ of the subjects (mainly males) follow an inadequate 
diet, which propitiates the atherogenic process, forasmuch as the consumption of food that provides an adequate nutritional intake is insufficient in comparison with the high consumption of refined sugars and saturated fats from another group of food for which individuals tend to opt more frequently, perhaps due to the university lifestyle and family customs.

Furthermore, $32.8 \%$ of this population of young adults reported being subjected to a medium level of stress, with the perception of stress being equivalent between women $(32.8 \%)$ and men $(32.8 \%)$. It is worth mentioning that the studied individuals noticed an increase in other cardiovascular risk behaviors associated with stress, such as the tendency to overeat, smoking, and alcohol consumption, in an attempt to reduce the sensation of stress in the organism. Despite the mechanisms through which stress is implicated as a CVRF are not fully understood, it is known that in a stressful situation, the adrenergic system is constantly stimulated, which is enough to increase blood pressure and produce endothelial harm ${ }^{9,20}$.

When contemplating that a large majority of the subjects have a significant family history of diseases (present exclusively or in association), as well as the sedentariness categorized in more than half of the sample, and the important percentage of individuals who follow an atherogenic diet, a relationship between these factors with the alterations found in the sample's anthropometric values could be established. These results are comparable with other studies carried out in Spain ${ }^{1}$ and in Peru ${ }^{19}$, in which it is also indicated that sedentary lifestyle affects women most of the time, with direct effects on their abdominal circumference and BMI. Nonetheless, men were not exempt from anthropometric abnormalities, given that $8 \%$ of the people in whom obesity was identified, a subtle majority was integrated by males, in whom alterations in abdominal circumference $(47.8 \%)$ and in the WHR (19.4\%) were also found, although in a smaller proportion.

In those subjects in whom blood pressure levels above the normality parameters were detected $(9 \%$ and $14.4 \%$ of individuals with values corresponding to prehypertension and hypertension, respectively) and who were mostly males $(16.4 \%$ with the first condition and $31.34 \%$ with the second one), it was observed a relationship with the referred record of antecedents of CVD in the family background and with alterations in the values of BMI, abdominal circumference, and WHR, which altogether could increase the rate of CVDs.

Despite the fact that drug addiction constitutes a relevant CVRF, smoking was not considered as a transcendent finding in this sample. On the contrary, alcohol consumption had a higher incidence $(64.1 \%$ of the subjects, with a higher proportion of males and with similar results in another study carried out in Chile) ${ }^{32}$, with a consumption of one up to four drinks with a frequency from 1 to 2 times/month.

In this sample, it was appreciated that habits and lifestyles can be established and even reaffirmed during youth. Therefore, if there is no emphasis on the modification of these patterns, that is, if behaviors such as sedentariness or consumption of alcohol and tobacco prevail, coupled with a poor diet quality and a strong genetic and family component, those individuals with normal weight could get into to the group of subjects with overweight and obesity, and those in whom any of these conditions were detected during the study, could aggravate their situation, and suffer a CVD with greater target organ damage from earlier stages. If this path continues, the impact will not be limited to the individual's health, but could eventually affect the economic activity of the country since the young population will be ill in their productive years ${ }^{18}$.

The main limitation of this study consisted of the impossibility to analyze biochemical variables, with the aim of assessing serum parameters such as HDL and LDL cholesterol, triglycerides, and glucose, which would have enriched the results by being useful in the measurement of vascular age with the QRISK algorithm, stratifying cardiovascular risk with the Framingham score and establishing criteria for the diagnosis of metabolic syndrome or diabetes mellitus. Nonetheless, in other similar studies carried out in Brazil ${ }^{22}, \mathrm{Cuba}^{38}$, India ${ }^{2}$, and Mexico $^{15}$, in which biochemical variables were taken into account, alterations such as dyslipidemia (characterized by high levels of LDL cholesterol and low HDL cholesterol and hypertriglyceridemia) and abnormal serum levels of glucose were identified in young individuals in whom, in turn, the confluence with other CVRFs (such as sedentary lifestyle, overweight, and obesity) was observed. This information suggests that alterations in these biochemical variables could also be found in the individuals who took part in the sample of this study.

\section{Conclusions}

The main CVRFs identified in this sample of young Mexican adults correspond to a high hereditary and family background of CVD burden, aggravated in turn by an insufficient level of physical activity (with higher incidence among women), an atherogenic diet (more 
frequent among males), a high level of stress, and a significant frequency of overweight (mostly women). The cases in which high blood pressure was detected were mostly males, showing a relationship with the referred record of antecedents of CVD in the family background and with alterations in their anthropometric values. Smoking was not considered a transcendent finding in this sample; on the contrary, alcohol consumption had a higher incidence, especially among males.

According to the categorization of CVRFs, the most frequently identified findings correspond to the group of modifiable minor risk factors, which could allow the development of preventive measures, inasmuch as they are subjects in which the modification of harmful behaviors and habits is achievable since they find themselves at a timely moment in which they own sufficient autonomy to take responsibility for their self-care.

Thus, further development of analytical research articles about CVRFs and CVDs in these age range (for which this study could serve as baseline) should be considered.

\section{Acknowledgments}

The author expresses his gratitude to Dr. Diana Fabiola Martínez Gómez for the provided time reviewing the present research study and for her constant support, to Dr. Seydi Itzel Sóstenes Ortiz for assisting in the registration of measurements, to the Health Research Department of ISEM for their guidance, and to the Faculty of Chemistry of the UAEM and the participants of this study for their collaboration.

\section{Funding}

The present investigation has not received any specific scholarship from agencies of the public, commercial, or non-profit sectors.

\section{Conflicts of interest}

None.

\section{Ethical disclosures}

Protection of human and animal subjects. The author declares that no experiments were performed on humans or animals for this study.
Confidentiality of data. The author declares that he has followed the protocols of their work center on the publication of patient data.

Right to privacy and informed consent. The author declares that no patient data appear in this article.

\section{References}

1. Vera-Martínez EJ, Monge RL, Chinesta SG, Rodríguez DS, Ramos MV. Factores de riesgo cardiovascular en adultos jóvenes de un centro penitenciario. Rev Esp Salud Pública. 2018;92:1-12.

2. Aggarwal A, Aggarwal S, Sharma V. Cardiovascular risk factors in young patients of coronary artery disease: differences over a decade. J Cardiovasc Thorac Res. 2014;6:169-73.

3. Mann DL, Zipes DP, Libby P, Bonow RO, Braunwald E, editors. Braunwald Tratado de Cardiología Texto de Medicina Cardiovascular. $10^{\text {th }}$ ed. España: Elsevier; 2016. p. 1-19.

4. Rosas-Peralta M, Arzimendi-Uribe E, Borrayo-Sánchez G. ¿De qué fallecen los adultos en México? Impacto en el desarrollo económico y social de la nación. La carga global de los padecimientos cardiovasculares. Rev Med Inst Mex Seguro Soc. 2017;55:98-103.

5. García-Gulfo M, García-Zea J. Prevalencia de factores de riesgo cardiovascular en jóvenes de una institución universitaria. Rev Salud Pública. 2012;14:822-30.

6. Secretaría de Salud. Guía de Práctica Clínica Detección y Estratificación de Factores de Riesgo Cardiovascular, México; 2010. Available from: http://www.cenetec.salud.gob.mx/descargas/gpc/CatalogoMaestro/421IMSS_421_11_Factores riesgo cardiovascular/IMSS 421_11 riesgocardiovascular.pdf. [Last accessed on 2019 Jan 22].

7. Organización Mundial de la Salud. Enfermedades Cardiovasculares, ¿Qué son las Enfermedades Cardiovasculares? 2019. Available from: https://www.who.int/cardiovascular_diseases/about_cvd/es. [Last accessed on 2019 Jan 07].

8. Organización Mundial de la Salud. Enfermedades Cardiovasculares, Prevención y Control de las Enfermedades Cardiovasculares; 2019. Available from: https://www.who.int/cardiovascular_diseases/es. [Last accessed on 2019 Jan 07].

9. Sánchez-Contreras M, Moreno-Gómez GA, Marín-Grisales ME, García-Ortiz LH. Factores de riesgo cardiovascular en poblaciones jóvenes. Rev Salud Pública. 2009;11:110-22.

10. Organización Mundial de la Salud. Prevención de las Enfermedades Cardiovasculares, Guía de Bolsillo Para la Estimación y el Manejo del Riesgo Cardiovascular. Geneva, Switzerland: Organización Mundial de la Salud; 2008.

11. Zócalo Y, Arana M, Curcio S, García V, Giachetto G, Chiesa P, et al. Daño arterial subclínico en niños, adolescentes y jóvenes. Análisis de la asociación con factores de riesgo, con la aterosclerosis del adulto y de su reversibilidad mediante intervención temprana. Rev Urug Cardiol. 2015;30:176-87.

12. Rodrigues NL, de Oliveira LH, de Sousa E, de Sousa PV, Gonçalves K, de Oliveira MV, et al. Risk factors for cardiovascular diseases in adolescents. Invest Educ Enferm. 2015;33:315-24.

13. Zea-Robles AC, León-Ariza HH, Botero-Rosas DA, Afanador-Castañeda HD, Pinzón-Bravo LA. Factores de riesgo cardiovascular y su relación con la composición corporal en estudiantes universitarios. Rev. Salud Pública. 2014:16:505-15.

14. Kammar-García A, López-Moreno $P$, Blásquez-Gutiérrez ME, Hernández-Hernández ME, Ortiz-Bueno AM, Martínez-Montaño ML. Relación de la hiperuricemia con las alteraciones metabólicas y factores de riesgo cardiovascular en jóvenes mexicanos. Gac Med Mex. 2019;155:236-42.

15. González C, Díaz Y, Mendizabal-Ruiz A, Medina E, Morales JA. Prevalencia de obesidad y perfil lipídico alterado en jóvenes universitarios. Nutr Hosp. 2014;29:315-21.

16. Alarcón M, Delgado P, Caamaño F, Osorio A, Rosas M, Cea F. Estado nutricional, niveles de actividad física y factores de riesgo cardiovascular en estudiantes de la Universidad de Santo Tomás. Rev Chil Nutr. 2015;42:70-6.

17. Castro JY, Abellán J, Leal M, Gómez P, Ortín E, Abellán J. Estilos de vida relacionados con el riesgo cardiovascular en estudiantes universitarios. Clin Invest Arterioscl. 2014;26:10-6.

18. Cruz-Sánchez E, Méndez MO, Cruz-Ramírez T, Bernardino-García A Vásquez-Domínguez L, Galindo-Palma N, et al. Factores de riesgo cardiovascular en estudiantes de enfermería de una universidad pública. Enferm Univ. 2016;13:226-32.

19. Peralta C, Loayza K, Medina-Palomina F, Rojas-Vilca J. Monitoreo domiciliario de presión arterial y factores de riesgo cardiovascular en jóvenes estudiantes de medicina de una universidad privada en Lima, Perú. Rev Med Hered. 2017;28:157-65.

20. Guadalajara JF. Cardiología. 6 ${ }^{\text {th }}$ ed. México: Méndez Editores; 2006. p. $771-83$. 
21. Secretaría de Salud. Guía de Referencia Rápida Detección y Estratificación de Factores de Riesgo Cardiovascular, México, 2010. Available from: http://www.cenetec.salud.gob.mx/descargas/gpc/CatalogoMaestro/421IMSS 421 11 Factores riesgo cardiovascular/GRR FACTORES_RIESGO_CARDIOVASCULAR.pdf. [Last accessed on 2019 Jan 22].

22. Barbosa JB, dos Santos AM, Barbosa MM, Barbosa MM, de Carvalho CA Fonseca $\mathrm{PC}$, et al. Metabolic syndrome, insulin resistance and other cardiovascular risk factors in university students. Cien Saude Colet. 2016;21:1123-36.

23. Organización Mundial de la Salud. Enfermedades no Transmisibles; 2019. Available from: http://www.origin.who.int/mediacentre/factsheets/ fs355/es. [Last accessed on 2019 Jan 07].

24. Lobos J, Brotons C. Factores de riesgo cardiovascular y atención primaria: evaluación e intervención. Aten Primaria. 2011:43:668-77.

25. Organización Panamericana de la Salud. Séptimo Informe del Comité Nacional Conjunto de los Estados Unidos de América sobre Prevención, Detección, Evaluación y Tratamiento de la Hipertensión Arterial. Available from: https://www.paho.org/hq/dmdocuments/2011/guia-hipertension-sp.pdf. [Last accessed on 2019 Feb 01].

26. Martínez J. Estratificación de riesgo cardiovascular. Arch Cardiol Méx. 2006;76:176-81.

27. Organización Mundial de la Salud. Enfermedades Cardiovasculares 2019. Available from: https://www.who.int/es/news-room/fact-sheets/detail/cardiovascular-diseases-(cvds). [Last accessed on 2019 Jan 07].

28. Diéguez M, Miguel PE, Rodríguez R, López J, de León DP. Prevalencia de obesidad abdominal y factores de riesgo cardiovascular asociados en adultos jóvenes. Rev Cubana Salud Pública. 2017;43:1-16.

29. Doménech M, Sobrino J. Prehipertensión en el paciente joven. Hipertens Riesgo Vasc. 2016;33:83-5.

30. Gutiérrez JP, Rivera-Dommarco J, Shamah-Levy T, Villalpando-Hernández S, Franco A, Cuevas-Nasu L, et al. Encuesta Nacional de Salud y Nutrición 2012. Resultados Nacionales. Cuernavaca, México: Instituto Nacional de Salud Pública; 2012.
31. Instituto Nacional de Estadística y Geografía (INEGI). Población; 2015 Available from: https://www.inegi.org.mx/temas/estructura. [Last accessed on 2019 Jan 16].

32. Bustos $\mathrm{P}$, Amigo $\mathrm{H}$, Arteaga $\mathrm{A}$, Acosta AM, Rona RJ. Factores de riesgo de enfermedad cardiovascular en adultos jóvenes. Rev Méd Chile. 2003;131:973-80.

33. Encuesta Nacional de Salud y Nutrición. Instituto Nacional de Salud Pública; 2016. Available from: https://www.ensanut.insp.mx/ensanut2016/descarga_bases.php\#.XG2QyKJKjIV. [Last accessed on 2019 Feb 14].

34. Cuestionario Internacional de Actividad física IPAQ. Available from: https://www.sites.google.com/site/theipaq/questionnaire_links. [Last accessed on 2019 Feb 14].

35. Preguntas Sobre Tabaco Destinadas a Encuestas. Serie de Preguntas Básicas de la Encuesta Mundial de Tabaquismo en Adultos (Conocida Internacionalmente Como Global Adult Tobacco Survey GATS). Organización Mundial de la Salud. Available from: https://www.who.int/tobacco/publications/surveillance/tqs_es_final.pdf. [Last accessed on 2019 Feb 15]

36. AUDIT Cuestionario de Identificación de los Trastornos Debidos al Consumo de Alcohol. Pautas Para su Utilización en Atención Primaria. Organización Mundial de la Salud. Available from: https://www.who.int/ substance_abuse/activities/en/AUDITmanualSpanish.pdf. [Last accessed on 2019 Feb 18].

37. Test de Estrés Laboral. Instituto Mexicano del Seguro Social. Available from: http://www.imss.gob.mx/sites/all/statics/salud/estreslaboral/ Test-Estres-Laboral.pdf. [Last accessed on 2019 Feb 19].

38. Diéguez M, Miguel PE, Rodríguez R, López J, de León DP, Reyna JL. Prevalencia de hipertrigliceridemia y factores de riesgo cardiovascular en estudiantes de la Universidad de Ciencias Médicas. Holguín, 20142015. Medisur. 2018;16:35-46. 